\title{
CONTEMPORARY PERSPECTIVES ON THE CHURCH AND CATHOLIC HIGHER EDUCATION
}

Usually more is gained at conventions by night-owl discussions, chance meetings, than by the sonorous pre-publication lectures delivered by distinguished personalities. The meeting of the International Federation of Catholic Universities held at New Delhi last August was hardly an exception to this "convention principle." True, discourses were at a minimum; it is also true that statements were made in the aula which have great import (provided they are implemented by our Bishops!) such as the clarification that the ruling forbidding laicized priests to engage in theology pertains basically to teaching seminarians and also the clear statement that the planned revisions of ecclesiastical studies also pertain to seminaries.

Nonetheless, many important matters were accomplished in the sweltering corridors of the Vigyan Bhavan Convention Center or on the all-day excursion to Agra, where the solemnity of the general meetings was transformed into a congeniality and openness impossible to achieve in a large auditorium filled with all the languages of Babel. One such informal conversation is especially significant for Catholic Colleges and Universities of the United States. Walking down the magnificent esplanade of the Taj Mahal, one of the most influential men in the Roman Congregation of Christian Education spoke up in these terms: "You know, there are two things which mystify us about the Catholic Colleges in the United States. The first is, why do so many appear to shrug off their 'catholicity' and secondly, why are Colleges, especially theology departments, so reluctant to cooperate with the hierarchy, especially the local Ordinary?"

Two undoubtedly serious questions. Serious not only because of their nature, but also because they are, apparently, uppermost in the mind of the Congregation. First of all, the questions reveal an ignorance and a fault. The ignorance is Rome's. They do not appear to understand fully the complicated American system of higher education and especially the delicate position of theology departments. The fault? It is ours. How often have we explained in detail, face to face, the enormous differences between the European system and the American, especially concerning theology faculties? Those of us who have studied in Europe can more readily appreciate the importance of this point. The questions ring out, therefore, a serious need: the College Theology Society (together perhaps with the NCEA) should be the spokesman for our departments of theology with the Roman Congregation. And this should be done not by mail, but by regular visits to the Congregation of Christian Education in order to keep them informed and also to keep us abreast of any hopes, or direc- 
tions which may be in the planning stage of the Congregation.

But the questions themselves. Why are so many Catholic colleges ashamed of being Catholic? Is this really the case? True, some Colleges and Universities, in order to receive necessary state aid, have reluctantly but openly declared themselves "non-sectarian" (with serious repercussions on the theology department) and are heading in the direction of formerly church-related institutions, such as Yale, Harvard, etc. Pressured by lack of funds, if not indeed bankruptcy, this appeared to be the only possible route for some of our colleges who understandably now find it difficult indeed to subscribe to the norms of "The Catholic University in the Modern World" (Rome, 1972).

But is there not another element to be considered? When religious communities, dioceses, are faced with serious financial problems, the Church rallies together to help such institutions, as we well know from recent events. Why could not the diocese at least issue an urgent appeal to its people to support the private Catholic college in their midst? Is it because (God forbid!) that some of our bishops did not believe that the College was worth saving and were only too happy to see it flounder? If so, the irreparable damage done to Catholic higher education is the fault of the nearsightedness of the American Catholic Church, which because of definite and emotional misunderstandings of the moment-which perhaps could have been cleared by dialogue or an arbitration board set up by CTS or NCEA-let important ships sink.

Hopefully, we have learned a lesson. On our part, we must realize that our survival as Catholic Colleges evidently depends upon the fact of our lived-out "Catholicity." Can we not say that President Ford was alluding to this when he declared in Dallas last September 13, "Private institutions can best serve by emphasizing their uniqueness, not by succumbing to any temptation to imitate the public university . . . they must offer something truly different, truly important." And the Holy Father, in his address to the Presidents of Jesuit Colleges forcefully insisted that the Church needs Catholic Universities and the Church wants them to be "Catholic." On the other hand, is there not also a serious obligation-so often overlooked-on the part of the Catholic community to support our private colleges which are struggling to exist? The Holy Father himself boldly stated: "In other words, the Church wants them (Catholic Colleges and Universities) to be "Catholic." And when she sees them truly so, she is prepared to give them all the help she can, even at the cost of great sacrifice." Many of our Catholic colleges, in order to remain "Catholic" desperately need this support which the Holy Father declares the Church is prepared to give us, as private institu- 
tions within the Roman Catholic family.

The second question. "Why," asked the Roman official, "is there such a lack of communication between the University and the hierarchy, between the University and the local Ordinary"? It is true that there is/was a breakdown in communications between the local Church and the University. The "theology problem" or campus ministry bears the brunt of the blame for this respectful (?) silence. And in some cases-no need to bring up examples-some of us theologians unnecessarily aggravated an already tense situation within the Church. Many a bishop considers the local Catholic college or university his "headache" which no excedrin will cure. Here again, when the local Ordinary and the College take up adversary positions and the problem cannot be resolved by "self-regulatory means" then the CTS and the NCEA should be invited to arbitrate. (This should also be the case when the problem is with the President of the University and the theology department, or as is sadly happening, when two small local Catholic colleges are engaged in a duel to the death).

The problem of lack of communication between University and diocese is partly the fault of the University and in some cases at least, particularly the fault of the theology department. Fine. But does not the fault also lie with the Bishops of our country? Do they truly understand the role of the theologian today and the differences between theology as taught in the local seminary and as taught in the College of Arts \& Sciences of a private University? How many times has the CTS volunteered its services to the Bishops and received only a token reply? In the preliminary Agenda for the Bishops' Meeting of 1975 , the CTS was not mentioned as an organization to contact in the anti-abortion drive, but the Holy Name Society was! (Perhaps the Bishops thought that by listing the Catholic Theology Society of America and Catholic Universities, there was no need of referring to the CTS?) How many Bishops understand that they have a goldmine in their backyard if they are fortunate enough to have a Catholic College or University in their diocese? Goldmines can also be headaches but one has the impression that some Bishops would rather ignore the treasure of the local University for fear of being accused of interfering, or of being connected with THAT College which some say is not upholding Catholic principles. Bishops will be surprised to learn how willing Catholic Colleges and Universities are to help them in their enormous burden of leading a diocese. Why do Bishops not use the specialists in Urban Affairs in their attempt to solve some of the problems of the inner city? Why not consult the medical school in order to understand the background of so many modern moral problems? And why not, as Cardinal Carberry has done in the Archdiocese of Saint Louis, form a Theology Commission made up of 
various theologians from the local University, from the diocesan clergy, where there are regular, open, free discussions of the theological problems facing the Archdiocese?

Both University and Church, strictly retaining their proper roles, will benefit by dialogue, mutual help. This is the wish of the Holy Father and was well explicated by Archbishop Bernardin: "The Catholic scholar is not and should not be regarded as a direct instrument or agent of the Magisterium any more than he or she should be regarded or regard himself as an alternative to the Magisterium.... The Catholic scholar's duty is to pursue the truth and to do so in the light of Catholic... tradition but not simply as the expositor and much less as the antagonist of that tradition. While there is an obvious tension in this relationship, there is, it seems to me, no reason why the tension should become conflict, unless one side or the other of the relationship chooses to make it such. On the contrary, the scholarly community has a definite and positive role to play in relation to the Magisterium and the entire Christian community" (NCEA, Occasional Papers, July 1975).

The questions raised on the esplanade of the Taj Mahal call for deep introspection on the part of American Catholic Colleges and Universities and also on the part of the American hierarchy. Perhaps the clue to the solution is the bold statement of the Holy Father: "The Church wants them [Catholic Colleges and Universities] to be 'Catholic.' And when she sees them truly so, she is prepared to give them all the help she can, even at the cost of great sacrifice."

\section{-J. PATRICK GAFFNEY, S.M.M.}

My colleague and friend, Patrick Gaffney, has written an essay that will, I believe, elicit comment. Pat's basic theme of dialogue and good channels of communication is unassailable in itself. But some of his remarks along the way trouble me.

First, he, like James Hitchcock and some others, seems to assume rather generally that Catholic colleges and universities are not really Catholic today. This is joined to a papal statement repeated two times that when the colleges and universities really are Catholic they will receive much help "even at the cost of great sacrifice." Will this "help" even be financial help? Who are these "some"? How many are they? In what way have they become non-sectarian?

Concerning all this, it seems clear that there is no financial plum available, and even if there were a cautionary approach would be necessary as would be the case in any situation of financial dependency. As John W. Donohue has remarked: ". . . neither Rome nor the 
local ordinaries are in a position to support even a medium-size university-and this is just as well. The presidents of state universities who must coax their budgets past legislatures know how hard it is to evade pressure from those who control the purse" (America 4/21/73, p. 358). But an even more fundamental question for scrutiny is the assumption that Catholic colleges and universities are not really Catholic anymore. It almost seems that whenever academic excellence is seriously pursued charges of imperiling an institution's Catholic character emerge. (I hope it is clear that I am not saying this is Pat Gaffney's view, but am articulating a point I believe needs emphasis today.) Permit me an historical example.

Bishop James H. Ryan, who served as rector of the Catholic University of America from 1928 to 1935, pushed a needed reorganization and move toward excellence for that institution. Ryan has been characterized as "a great academic organizer" and a person of "remarkable foresight." He was, however, ousted in 1935, because a powerful member of the board of trustees, John T. McNicholas, O.P., archbishop of Cincinnati, objected to his efforts to raise standards to that of "a Catholic Harvard." John Tracy Ellis has commented that "McNicholas and his followers interpreted this goal as secularization in a doctrinal sense and felt that it constituted a serious threat to the university's character as a Catholic institution. McNicholas convinced the apostolic delegate of the alleged danger, and Ryan was removed as rector and named Bishop of Omaha (Neil McCluskey, ed., The Catholic University: A Modern Appraisal, p. 251).

Are goals of excellence antithetical to the Catholic character of an institution? Is George Bernard Shaw really to be accepted after all in holding that "Catholic" and "university" cannot go together? Catholic colleges and universities have made some encouraging progress in improving their academic quality in the last ten years. Has this not enhanced rather than diminished the chances of their Catholic character? It is no time to go slow on goals of academic excellence, and Catholic colleges and universities that do will do so at the expense of their authentic being. In a recent speech in Philadelphia to the N.C.E.A., Msgr. John Tracy Ellis has once again exhorted Catholic higher education to examine the quality of its offerings and to avoid the "cloud of mediocrity" in which it has tended at times to become enveloped.

This is not to say that the question of Catholic identity is not important. It is important; but academic mediocrity will not contribute to its solution. Frankly, I think Catholic colleges and universities are increasingly Catholic. The Land o' Lakes Statement (1967) on "The Idea of a Catholic University" has observed that universities serve as a critical reflective community for society, and that in keep- 
ing with this general function "the Catholic university has the added obligation of performing this same service for the church."

Hence the university should carry on a continual examination of all aspects and all activities of the church and should objectively evaluate them. The church would thus have the benefit of continual counsel from Catholic universities. Catholic universities in the recent past have hardly played this role at all. It may well be one of the most important functions of the Catholic university of the future.

It has been almost ten years since this statement was made, and important progress and Catholic service has been achieved by Catholic colleges and universities in accord with the above. Nor has this by any means been the only expression of their Catholicity.

The second question addressed in Pat's essay concerns an alleged reluctance to cooperate with local bishops. Here I find his remarks on the appropriateness of dialogue, mutual respect and cooperation welcome enough, but a bit naive-e.g., ". . . when the local Ordinary and the college take up adversary positions and the problem cannot be resolved by 'self-regulatory means' then the CTS and the NCEA should be invited to arbitrate." Sad to say, relationships between bishops and Catholic colleges and universities still too often proceed in terms of power relationships. Where this is not the case, arbitration is not needed; where it is the case, arbitration is not wanted.

It seems to me that the power game is still going on in the latest Roman communication on "definitive academic legislation for the Church." Under "agreed norms" we read:

It is certain that higher sacred studies, above all theological studies strictly so-called, by their nature are exclusively subject to the authority of the sacred hierarchy, even if it is a question of faculties or higher schools in state universities or private Catholic universities that are not canonically erected.

If this was meant to apply to seminaries rather than colleges and universities as the informant indicates in the first paragraph of Pat's essay, they certainly chose their words carelessly. This is, of course, a tentative draft, and as Pat says, there is much misunderstanding by Rome of North American higher education, but there remains a continuing Roman problem of sinning by excess in regard to assertions of power and dominion.

Finally, there is the highly practical question of the Roman attempt to forbid laicized priests to teach theology. It is encouraging to hear that this curious concern with marital state rather than teaching competence is to be restricted only to seminaries. CTS members 
can be commended for this. The national CTS resolution supporting faculty appointments on normal academic criteria, which was passed in Los Angeles in 1972 and subsequently supported by the Catholic Theological Society of America and the International Federation of Catholic Universities, has been of some value in this.

As Pat says, more dialogue is needed among concerned parties on these issues. The International Federation of Catholic Universities has provided one forum. Another has been a commendable conference held at the University of Notre Dame in January 1976. The NCEA can and does make its contributions. For the most part, however, these gatherings have been exchanges among the "managerial classes" whether ecclesiastical or academic. Perhaps professorial laboring types whether teaching in Catholic schools or not will now wish to contribute their dimension to these matters. Readers' contributions are invited on all materials published in Horizons.

-ROGER VAN ALLEN 


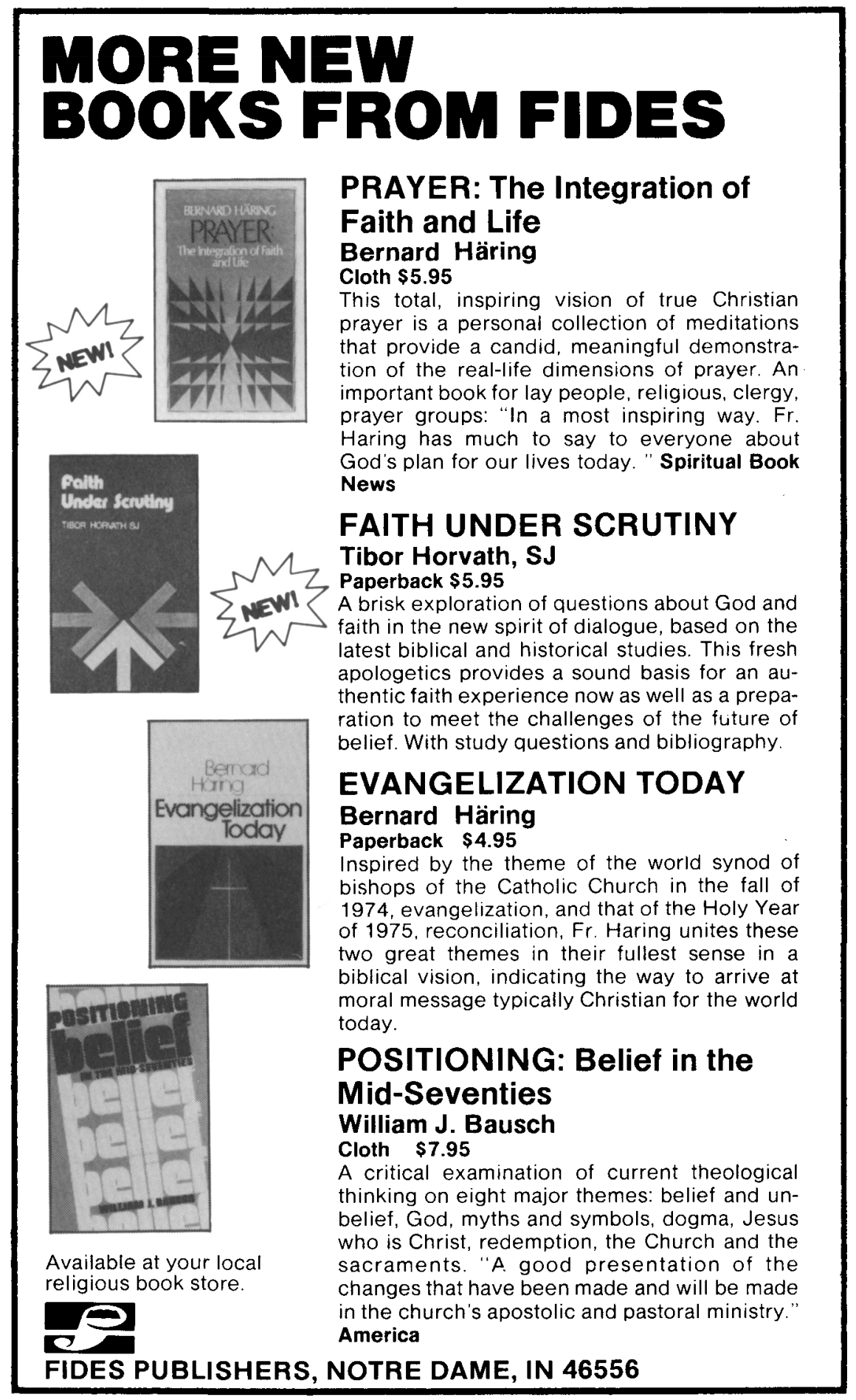

